\title{
A CIDADANIA DE ZÉ FRANCISCO E A HISTÓRIA 'FEITA DE BAIXO': OS MOVIMENTOS SOCIAIS DE LUTA PELA TERRA. PARTE 2: A REFORMA AGRÁRIA E O CAMPESINISMO NO FUTURO BRASILEIRO (1989-2013)
}

The citizenship of Zé Francisco and the history 'made of low': The social movements of fight for the earth. Part 2: Agrarian reform and campesinism in the brazilian future (19892013)

Colin Henfrey (Univ. de Liverpool, Inglaterra)

Informações do artigo

Recebido em 02/05/2018 Aceito em 03/06/2018

doi>: $10.25247 / 2447-861 X .2018 . n 245 \cdot p 624-660$

\begin{abstract}
Resumo
Como em sua primeira parte, este artigo deriva de matéria antropológica e oral coletada ao longo de 40 anos, principalmente na Chapada Diamantina baiana. Em forma narrativa, continua a história da mesma família extensa envolvida na luta pela terra nos anos setenta e oitenta. $\mathrm{Na}$ década seguinte, suas segundas e terceiras gerações contribuíram decisivamente para o sucesso do MST em mobilizar as ocupações e acampamentos, cuja transformação em assentamentos prometeu um futuro mais justo para a região. Porém este futuro ainda está tardando, ao ponto de os assentamentos servirem como 'exércitos de reserva' para o agronegócio local. $\mathrm{O}$ artigo sugere que a possibilidade deles se constituírem em uma alternativa sustentável ao domínio do agronegócio dependerá de dois processos: um novo padrão, descentralizado e democrático, de 'desenvolvimento feito de baixo'; e um novo projeto político, promovendo esse tipo de solução à duradoura questão agrária brasileira e suas consequências sociais mais amplas.
\end{abstract}

Palavras-chave: Reforma Agrária. MST. Assentamentos, campesinato, 'campesinismo', Desen-volvimento de baixo para cima. Chapada Diamantina.

\section{Abstract}

Like its first part, this article is based on anthropological and oral material gathered over some 40 years, mainly in Bahia's Diamond Plateau region. In similarly narrative style, it continues the history of the same extended family involved in the land struggles of the 1970--80s. In the following decade, described here, its second and third generations contributed significantly to the success of the Landless Movement in mobilising the land occupations and encampments whose transition to reform settlements promised the region a more just future. However this future is still delayed, to the extent of the settlements increasingly serving as 'reserve armies' (of labour) for local agribusiness. In conclusion, the article suggests that the possibility of their becoming a part of a sustainable alternative to the dominance of agribusiness will depend on two processes: a newly decentralised and democratic style of 'development from below' and a new political project promoting such a solution to Brazil's persistent agrarian question and its societal consequences.

Keywords: Agrarian reform. The Landless Movement. Reform settlements, peasants, 'peasantness', development from below. Chapada Diamantina (Brazil). 


\section{A Chapada parada: a paralisação da reforma agrária nos anos 1980-90}

Durante quase uma geração, nos anos 1970-1980s, na Chapada Diamantina da Bahia, acompanhei os sonhos, sucessos e recuos das lutas pela terra descritas na primeira parte deste estudo (HENFREY, 2017). Voltando nos fins de 1989, encontrei uma situação desoladora.

Nos meados da ditadura, em 1975, fui atraído à região, pela primeira vez, por um leve sinal de esperança de um futuro agrário mais justo do que aquele imposto pelo regime militar: a resistência de uma pequena comunidade camponesa ao seu despejo da terra pela grilagem e especulação surgidas no país inteiro. Os líderes daquela comunidade, no município de Iramaia, não só protestavam, com risco da própria vida, aos órgãos da imprensa e ao governo, como, também, por baixo do pano, começavam a reocupar um terreno. Conhecido como Toca da Onça, era vizinho àquele de Limpanzol, de onde haviam sido despejados em 1972, quando a área foi engolida pelo latifúndio enorme de Floresta do Rio Una e permaneceu improdutiva, apesar de receber crédito subsidiado da SUDENE e do Banco Mundial, um caso típico da época e da região.

Pouco a pouco, o povoado clandestino da Toca da Onça foi crescendo com a chegada de umas 20 famílias sem terra, oriundas de Rumo, um subdistrito de Itaeté, o município vizinho, onde trabalhavam como diaristas nas fazendas. Efetivamente, recriavam a antiga comunidade de Limpanzol, na qual a maioria deles morava antes do despejo. Em 1981, esta 'recamponizacão' se acelerou, quando os supostos donos da área, herdeiros de um coronel grileiro, ameaçaram despejá-los para vendê-la, provocando uma ocupação em massa, por dezenas de famílias sem terra. Apesar de serem expulsas pela polícia militar, as 20 famílias originais conseguiram ficar, através de um acordo feito pelos advogados da Comissão Pastoral da Terra (CPT) com o comprador especulativo que, como candidato a deputado estadual pelo PMDB, temia aparecer como grileiro. O povoado sobreviveu, restrito a uns cento e sessenta hectares de terra, no meio dos dois mil hectares.

O caso de Toca da Onça tornou-se o primeiro passo numa onda de reocupações de terra mais extensivas na região, desde os municípios de Andarai e Wagner, na Chapada, acima de Itaeté, até Marcionílio de Souza, laçu, Itaberaba e Boa Vista do Tupim, no vale mais abaixo, nas duas margens do rio Paraguaçu. No clima da 'distensão política' dos anos oitenta, a evolução dessa resistência camponesa, num movimento social apoiado pela CPT, a 
Associação de Advogados de Trabalhadores Rurais no Estado da Bahia (AATR) e as novas entidades trabalhistas e políticas da CUT Rural e do PT, fazia parte da nova esperança nacional de uma democratização radical do campo. A expectativa era de uma reforma agrária que daria acesso equitativo não somente à terra, mas, também, aos recursos econômicos e sociais do estado, desde o crédito e assistência técnica até os serviços de educação, saúde e moradia melhor para todos.

Porém, entre o sucesso e a euforia da mobilização social e a conquista dos seus alvos existe o abismo econômico e político onde tantas esperanças evaporam - ainda mais no caso da política brasileira e na crise econômica dos anos oitenta. Com o fracasso da Campanha pelas Diretas, em 1985, a sucessão presidencial do latifundiário José Sarney sequestrou a proposta da CUT Rural de uma reforma agrária popular, 'massiva e sob o controle dos trabalhadores'. Com seu Primeiro Plano Nacional de Reforma Agrária (PNRA), imposto de cima para baixo, freavam-se as expectativas de justiça agrária no país inteiro. Sob aquele Plano fantasma, de 1985-9, só $6 \%$ das 1.4 milhão de famílias previstas foram assentadas (BRASIL/INCRA, 2016). No caso da Bahia, os números foram ainda menores, cerca de 2\%, a maioria em áreas já ocupadas por iniciativa dos próprios camponeses. No caso da Chapada, as únicas três desapropriações daqueles anos (das quais a maior foi Canabrava, em Boa Vista de Tupim, com umas 320 famílias), com a falta e o atraso da assistência prometida, ficaram no limite da sobrevivência. Como sempre, as vítimas seriam culpadas pelos fracassos daquilo que os ruralistas depois chamariam de 'favelas rurais', criadas, de fato, pelas falhas das próprias políticas do governo.

Todavia, na Chapada se notava, também, um declínio interno no movimento, que não respondeu ao vácuo, por parte da classe política, com novas ocupações de terra. A primeira parte deste estudo atribuiu a força original dos movimentos sociais no campo à dinâmica das distintas histórias regionais dos próprios campesinatos, mas, igualmente enfatizou a importância logística e programática, na conjuntura dos anos oitenta, das alianças mais amplas com as entidades de apoio, eclesiásticas e civis, trabalhistas e políticas. Nenhuma destas, desde a CPT até a CUT e o PT, tinha como referência, em seu projeto central, a questão complexa do papel dos camponeses (ou seja, neocamponeses) numa futura e 'moderna' sociedade brasileira.

A única entidade com tal missão foi o MST. Desde sua fundação, em 1984, no Rio Grande do Sul, sua influência se espalhava, mas, até 1989, só havia chegado ao Sul da Bahia. 
Nos meados daquele ano, eu tive a oportunidade de conhecer o Movimento, tanto nos lugares lendários da sua origem, como Ronda Alta e Encruzilhada Natalina, no Rio Grande do Sul, como, também, na ocupação recente de Mariana, no sul da Bahia.

Aquelas experiências me deixaram com certas dúvidas sobre o potencial do MST para representar o neocampesinato nacionalmente. Para começar, havia a particularidade das suas raízes no campesinato do extremo Sul, de origens tão europeias e recentes, bem distantes, por exemplo, das histórias e culturas ou visões de mundo dos campesinatos nordestinos ou amazônicos. Outra questão era a alegada falta de democracia interna na conduta do Movimento, já comentada e, mais tarde, reconhecida até por simpatizantes anteriores (NAVARRO, 2002).

Minha primeira avaliação destas questões era tentativa. O projeto do MST, de criar um movimento camponês nacional, era profundamente ambicioso e complexo, tanto em função da sua escala e das distâncias no Brasil, como, também, dos aspectos históricos e sociológicos envolvidos. Qualquer campesinato, senão o mero 'saco de batatas' de Marx, era muito menos homogêneo e integrado que qualquer proletariado; por este motivo, organizálo sem ser autoritário exigia um alto grau de sensibilidade social e imaginação política. Isto seria necessário para o MST combinar sua força com a dos movimentos locais nascidos 'de baixo', como no caso da Chapada, marcada por uma cultura camponesa primordialmente democrática, porém patriarcal (o que depois diminuiria). Enraizada no processo da fundação autônoma de povoados como Limpanzol e Toca da Onça, esta cultura democrática reemergiu primeiro nas Comunidades Eclesiais de Base e, depois, nas delegacias sindicais nas comunidades: a representatividade destas foi o sangue nas veias do desafio à ordem social representado pelas ocupações. Estaria o MST, com sua cultura alegadamente autoritária e frente a uma tarefa exigindo certo grau de centralismo, capaz de se integrar e interagir com aquela democracia da base?

Foi com estas questões na cabeça que voltei à Chapada nos fins de 1989 - o ano mais desastroso de todos para a redemocratização, com a campanha presidencial de Lula subvertida pela Rede Globo em favor de Collor de Mello, cuja corrupção e neoliberalismo acabariam com qualquer pretensão a uma reforma agrária equitativa.

A situação na Chapada foi um espelho daquela crise. Localmente, na Toca da Onça, depois do acordo de 1981, suas vinte famílias tinham um retorno duro, mas estável, a uma vida camponesa quase autossuficiente. A água vinha somente do Rio Una, um quilômetro 
distante, mas não faltava, e a luz era apenas de candeeiros, mas ninguém reclamava: nas noites de lua cheia, os vizinhos andavam de casa em casa, conversando e compartilhando as tarefas de descascar o milho e o feijão. Naquelas noites, hospedado por eles, passei horas conversando em redor da fogueira e anotando os detalhes da sua vida cotidiana. Com três anos de chuva regular, ninguém precisava sair para trabalhar como diarista. Apesar de seu tamanho restrito (400 tarefas), a comunidade consolidou-se. Seu líder, Zé Francisco, montou uma nova casa de farinha. Da prefeitura de Iramaia, conseguiu-se a construção de uma escola com uma sala, mas bastava. Ali Arlito, o neto de Zé Francisco, ensinava seus primos e vizinhos, como tinha feito informalmente, desde menino, quando, no Rumo, só ele havia tido condições de estudar a primeira série. Finalmente, a comunidade fez sua declaração de permanência definitiva, na forma do campo de futebol: ali, no frescor e sombra do poente, Zé Francisco sentava com seu neto mais jovem - Zé Neto - no seu joelho para assistir os jogos.

Contudo, dos meados da década dos oitenta em diante, a fragilidade daquela vida camponesa reconquistada, mas apertada, reapareceu com a volta da seca. Nas roças, a única produção foi das culturas mais resistentes, de mandioca e mamona, e, mesmo estas, também diminuíram. A terra cansava e o cansaço acelerava-se pela subdivisão dos lotes, quando os jovens precisavam de um pedacinho. A pouca assistência que chegava criava mais problemas do que resolvia. Os créditos do banco, trazidos pelos técnicos da EMATERBA (Empresa de Assistência Técnica e Extensão Rural-Bahia), disponíveis apenas para monoculturas comerciais expostas a riscos, como algodão, reduziram a produção das culturas tradicionais de autoconsumo, mais adaptadas ao clima e integrais ao bem-estar familiar. Muitas das dívidas consequentes no banco foram pagas, cortando-se as árvores que restavam e vendendo-se a lenha para carvão, acelerando a desertificação da área, já sem terra para a nova geração. Na sua velhice, Zé Francisco viu-se forçado a virar 'gato', vendendo o trabalho diário dos seus filhos aos fazendeiros. Naquela situação, a pouca terra de que eles dispunham para seu autosustento teve o efeito perverso de subsidiar a diária abaixo do salário mínimo que os fazendeiros locais pagavam. Assim, como 'exército de reserva' meio camponês, os ocupantes sofriam uma dupla subordinação ao capitalismo primitivo dos novos latifundiários.

Na região inteira, a situação era semelhante. Nas comunidades de posseiros estáveis, durante gerações, como Morro Branco em laçu, e até nas áreas desapropriadas, como Canabrava em Boa Vista de Tupim, os jovens voltaram a trabalhar nos canaviais e na construção civil em São Paulo; os velhos sobreviviam minando até as raízes das últimas 
árvores, que acabavam como carvão para as usinas da Volta Redonda. No vale inteiro, os fornos de barro primitivos, bufando fumaça e cheios de meninos meio-nus trabalhando por mixarias, pareciam uma imagem do Inferno de Dante. O quadro ilustrava o que, em breve, seria um tema central da ECOg2 no Rio: a correlação da sustentabilidade com a equidade social e, portanto, inversamente, a degradação ambiental como resultado da desigualdade (UNITED NATIONS, 1987). Os pobres minavam e acabavam com a natureza do 'mundão véio' de Zé Francisco, por serem, agora, despossuídos de recursos suficientes para trabalhar sustentavelmente; ao mesmo tempo, os proprietários do mundo novo também minavam a natureza, pelos motivos contrários de terem recursos irrestritos e interesse apenas no lucro a curto prazo (BRYANT \& BAILEY, 1997).

No Rumo, onde muitos dos despejados de Limpanzol e do enfrentamento da Toca da Onça ainda moravam, sua vida proletária se equilibrava. Poucos tinham expectativas de voltar à vida camponesa. Para os jovens e fortes, o trabalho assalariado, anteriormente limitado aos dias limpando as plantações das fazendas, agora ficava mais diversificado. 0 dono da farmácia e chefe político de Rumo comprou um cafezal na serra, para onde levava homens, mulheres e crianças para trabalhar nas safras. Nas condições dos anos oitenta, até os sindicatos da CUT tinham pouca influência sobre as condições de trabalho e o preço pago pela produção. O preço era baixíssimo, a viagem incômoda, a acomodação desumana e o trabalho apenas sazonal, mas, pelo menos, quando havia, durava duas ou três semanas.

Entre aqueles trabalhadores estavam Maria, sobrinha de Zé, e seu marido Del. Como muitos outros, desde o despejo, não queriam saber mais da insegurança de viver como posseiros: ao invés disto, resolveram usar o pouco que o lugar e o tempo ofereciam, para criar uma vida nova. As lutas, naquele mundo transformado, eram mais pessoais do que coletivas. Apesar de já ter quatro filhos, o casal costumava trabalhar junto, levando-os para os cafezais. Assim conseguiram construir uma casa pequena na periferia de Rumo, onde, durante um tempo, aluguei um quarto. Mulher de muita raça, Maria sempre fazia questão de conseguir mais para a família do que a mera sobrevivência. Um dia, na única loja de móveis em Itaeté, viu uma mesa bonita, de fórmica vermelha, custando o equivalente a mês de trabalho nos cafezais, e resolveu voltar para comprá-la. Estava grávida de novo, já com cinco meses, mas, para ela, isso não foi obstáculo: com o aluguel que paguei, garantiu a primeira prestação, para 'segurar a mesa', e foi novamente aos cafezais. Três meses depois de voltar, o nenê nasceu sem problema e celebramos, comendo juntos em redor da mesa vermelha. 
Para outros sobreviventes do despejo de quase vinte anos antes, as consequências pesavam mais. Nos primeiros anos, Loura, viúva de Missias, trabalhava como empregada doméstica para o mesmo chefe político de Rumo; mas, como ele pagava pouco, saía para lavar a roupa dos outros no rio. A cada dia, debaixo do sol quente, levava a roupa molhada e pesada na cabeça; de volta para casa, de noite, passava a roupa com o ferro esquentado a lenha. Mas, sem marido ou condições de construir uma casa nova, teve que pagar aluguel e, por mais que trabalhasse, não conseguia manter a família: desde menina sua filha Edineuza teve que ser entregue a uma senhora de Itaeté, que buscava ajuda doméstica.

Quanto a Nêga, esposa de Antônio Miguel, que, para a febre da beira do rio perdeu seus dois meninos no despejo de Limpanzol, não podia sair para trabalhar por precisar cuidar da filha, Marinalva, que sofreu um dano cerebral provocado pela mesma febre. Felizmente, ainda contavam com o apoio do outro filho, Edivando, para ajudar a sustentar a família e pagar, na farmácia, a despesa constante dos remédios para Marinalva. Trabalhando juntos, pai e filho 'se viravam' de uma solução para outra, arrendando um pedacinho de terra em qualquer canto em que podiam. Inicialmente, ainda perto de Rumo, cultivavam amendoins, que eles torravam para vender nas feiras. Porém, agora, a única terra disponível estava na serra, onde Antônio Miguel ficava sozinho, só voltando no fim de semana, por ser tão longe. Para não depender somente disso, Edivando, agora, trabalhava como diarista nas fazendas, quando achava vaga; quando não, ajudava seu pai na serra.

Um dia fomos juntos à serra. Levamos quatro horas a andar. A terra da roça, de duas tarefas, era pobre: só dava para mandioca. Para arrendá-la, Antônio Miguel pagava a meia da produção modesta ao gerente do suposto dono, o filho do grande latifundiário, Zé Américo. Voltando sozinho, eu saí cedo, à tarde, debaixo dum sol ainda quente. Na descida, minha sede foi agravada pelo som constante da água vindo dum poço acima, tilintando num cano que a levava para o gado beber na fazenda Brasileia, no pé da serra abaixo; além da Colônia, quase tudo agora estava nas mãos de fazendeiros. Antes da minha chegada, anoiteceu. Longe, mais abaixo, as luzes de Rumo eram uma ilha pequenina, perdida na imensidão da escuridão despovoada.

Eu não sabia, então, que uns vinte anos passariam antes que eu voltasse a ver aquelas terras; e muito menos imaginava como seriam transformadas. 


\section{A Nova Chapada (2013): o MST e as redes sociais e familiares na fundação dos assentamentos}

O único ônibus de Itaberaba para Rumo saiu de tarde. Passando por Itaeté, dava para perceber uma paisagem nova, com as águas das cabeceiras do rio estendidas em redor da cidade pela nova represa de Bandeira de Melo, o povoado vizinho. No pé da ladeira, na subida da estrada para Colônia e Rumo, lembrei-me da favelinha dos novamente despejados que eu vi com Zé Francisco, na minha primeira visita, quase quarenta anos antes. Era agora uma zona urbanizada, com luz e edifícios. Tanto nestas cidadezinhas, como no próprio campo e até nas margens das cidades grandes, foram tipicamente os pobres que criaram estas fronteiras, dando um valor de mercado à terra, antes de serem expulsos, para começarem de novo. $\mathrm{A}$ estrada para Rumo ainda era de cascalho, meio visível na luz do poente, o sol baixando detrás da serra. Lembrei-me do último passeio que eu fiz em 1989, para visitar Antônio Miguel, voltando numa hora como essa, ouvindo o som da água presa, e guiado só pelas luzes de Rumo, sozinho no meio da terra cativa.

Não foi por falta de interesse que vinte anos haviam passado desde minha última visita: porém, na ausência dos meios de comunicação de hoje e apesar da nossa longa amizade, eu sabia somente que meu amigo Zé Francisco havia falecido em 2000, com oitenta e quatro anos. Fora disto, eu tinha perdido contato com o pessoal e as notícias da Chapada, Rumo e Toca da Onça. Daí minha surpresa quando, no meio do caminho escuro, de repente havia luzes e, em vez de seguir para Rumo, o ônibus virou à direita. Na esquina vi uma placa: 'Assentamento Baixão'.

Logo adiante, chegamos a uma praça larga e bem iluminada. No centro havia a bandeira do MST, com seu desenho heroico: o mapa do Brasil em verde, o casal trabalhador no meio, e, em redor branco, para a paz, e vermelho para as lutas no campo. As casas na praça eram modestas, mas bem construídas, a maioria rebocadas, com quintais no fundo plantados com bananeiras, mamoeiros e outras fruteiras e verduras. A chegada do ônibus foi movimentada: famílias inteiras desciam com suas compras de Itaberaba, enquanto outros entravam para seguir para Rumo. Antes, houve outra parada, na Colônia dos pequenos produtores, que eu tampouco reconhecia, por ser tão transformada. Igualmente iluminado, tinha árvores maduras ao longo de uma rua de pequenos comércios: uma vida social e o renascimento da natureza no espaço anteriormente sempre mais despovoado e desmatado. Depois paramos junto a uma outra entrada onde havia mais uma placa: 'Assentamento 
Valdete Correia'. Valdete Correia? Era o nome da filha querida de Zé Francisco e Dona Maria, e mãe de Zé Neto, que os velhos criavam. Hoje, Valdete teria uns cinquenta anos. Percebi que, no Rumo, haveria muitas notícias para atualizar-me.

Eu sabia que, nos últimos dez anos, a reforma agrária tinha sido reativada, principalmente pelo esforço do MST e a eleição, em 2002, de Lula como presidente. Também conhecia as estatísticas mostrando o alto número de assentamentos na Bahia, especialmente na Chapada. Mas nada me havia preparado para esta transformação da paisagem e, sobretudo, das pessoas, tão envolvidas em atividades autônomas, ao invés daquelas impostas antigamente pela pobreza e desigualdade. Deu-me a sensação de assistir a uma emancipação múltipla: da terra, da natureza e, acima de tudo, das pessoas.

No Rumo do qual eu me lembrava, a praça central só tinha um bar, pouco frequentado, cujo sistema de som quase sempre tocava a mesma música, o 'Imagine' de John Lennon; dia a dia, seu sonho de um mundo sem injustiça ecoava, surrealisticamente, em meio ao calor e pobreza daquele povoado dos despejados. Agora, demorei em orientar-me: seria a mesma praça? Esta tinha árvores, luzes e um coreto; os jovens andavam de motocicleta. Os burros, que, junto com o canto do galo, sempre haviam me acordado, pareciam quase extintos. Ainda desorientado, pedi informações para chegar à Rua do Rio, onde eu havia me encontrado pela primeira vez com a família de Zé Francisco e o pessoal de Limpanzol e Toca da Onça. Aqui as luzes eram mais fracas e as casas quase as mesmas daquele tempo, algumas rebocadas, mas outras ainda de taipa e telhas velhas, porém com ocupantes diferentes: conheciam a família Correia, de Zé Francisco, muitos dos quais agora moravam nos assentamentos, informaram-me. Porém Arlito, o neto de Zé, de quem eu me lembrava como o professor jovem da escolinha da Toca da Onça, morava numa casa na esquina da estrada de Itaeté. Fui procurá-lo.

Imediatamente reconheci seu rosto sorridente e inteligente, agora um homem de quarenta anos. Abraçou-me e apresentou a família: sua esposa Celine, professora da escolinha, depois de Arlito sair para estudar no ginásio de Itaberaba, e suas filhas, Maísa de vinte anos, com um filhinho de um ano, e Maíra de quatorze, e a mãe de Celine. A casa era igual às outras do centro original do povoado, quase todas no estilo tradicional, com a frente beirando a rua, onde, pelas janelas abertas, se saudava ou se conversava com quem passava. Por dentro, a casa era mais profunda do que parecia de fora, estendendo-se até a cozinha semiaberta no fundo. A pensão estava fechada, Arlito avisou-me, convidando-me a ser 
hóspede deles. Na casa ampla, despretensiosa e confortável, o ambiente agradável de quatro gerações recriava a sensação com que esta família extensa sempre me havia honrado, de ser bem-vindo e compartilhar o que eles tinham. Foi difícil deixar passar o contraste entre isto e a falta histórica de generosidade para eles por parte do resto da sociedade brasileira.

Por ser um sábado, dava tempo para as jovens olharem o álbum que eu tinha trazido, com fotos datando das minhas primeiras visitas: mostravam seus avós ainda jovens, seus tios e Arlito ainda meninos, primeiro no Rumo e, depois, na escolinha e nas roças de Toca da Onça. Reparavam que, naquele tempo, tão distante para eles, mas, na realidade recente, os meninos às vezes andavam descalços. Depois, conversando até tarde, Arlito me atualizou sobre os vinte anos passados. O motivo do assentamento no caminho de Itaeté ter o nome de Valdete Correia era que esta filha adorada de Zé Francisco havia falecido jovem, de um enfarte, só quatro anos depois do seu pai, já herdeira do espírito dele, como uma das mobilizadoras principais das ocupações locais da terra.

Nos dias seguintes, conversando mais com Arlito e percorrendo os assentamentos associados com Rumo e Toca da Onça, aprendi as origens deles. Foi nos meados dos anos 90 que se ouviu falar, no Rumo, da chegada do MST, primeiro no município de Wagner, na zona alta dos cafezais, onde a especulação da terra ainda era forte. Com o fracasso do Primeiro PNRA e o fortalecimento da aliança nacional e regional dos fazendeiros e grileiros armados da União Democrática Rural (UDR), os despejos de posseiros e outros pequenos agricultores nesta zona se intensificaram. A tentativa de reocupar uma área grilada, Águas Belas, provocou uma reação tão violenta dos donos de terra, organizados entre si e apoiados pela polícia, que a CPT de Itaberaba chamou o MST para ajudar. Bem estabelecido, agora, nas ocupações no sul da Bahia, e com sua direção estadual e influência no INCRA consolidadas em Salvador, o Movimento respondeu logo. Mandou militantes para abrir uma nova frente na Chapada. Estes conseguiram a desapropriação de uma área perto de Águas Belas, onde, em junho de 1997, foi criado o assentamento São Sebastião da Utinga, o primeiro do MST na Chapada.

Da serra, o Movimento desceu, ainda em 1997, para Boa Vista de Tupim, onde a presença do assentamento de Canabrava, datando de 1986, ajudou na ocupação e desapropriação da fazenda vizinha de Beira Rio. Somando mais de 600 famílias, as duas áreas recriaram algo das expectativas da década dos oitenta, quando, pela primeira vez, a dominação do latifundismo regional foi desafiada pela mobilização camponesa, apoiada pela 
CPT de Itaberaba. Agora, com tantas famílias sem terra no Rumo e entre os jovens da Colônia, o Movimento não demorou a atravessar o rio, de Boa Vista para Itaetê. Ainda no mesmo ano 1997, a primeira ocupação no município foi formalizada pelo INCRA, com a emissão da posse da terra do assentamento Rosali Nunes. O nome comemorava uma das heroínas do MST, morta no enfrentamento famoso da ocupação da fazenda Anoni, no Rio Grande do Sul.

Apesar da imagem do Movimento, enfrentadora, segundo a mídia, e heroica para seus fiéis, sua atuação principal era construtiva e dentro da lei: articulava as demandas dos sem terra e a disponibilidade de propriedades improdutivas nas regiões com a burocracia remota e metropolitana do INCRA, paralisada pela inércia e a falta de recursos, pressionando-a a realizar as reformas propostas desde o PNRA. Chegando à Chapada, os militantes começaram por desenvolver contatos com líderes atuais e potenciais nas comunidades dos sem terra, como a de Rumo. Usando o conhecimento local destes novos militantes de base e suas redes familiares, identificavam fazendas improdutivas ou abandonadas e faziam reuniões clandestinas, para mobilizar o número máximo de famílias para montar uma ocupação. Assim, obrigavam o INCRA a fazer uma vistoria, justificando a expropriação com base na improdutividade e, depois de um acordo com o antigo proprietário, lançavam o processo de estabelecer o assentamento. Em colaboração com a associação eleita pelos ocupantes e com técnicos da Assistência Técnica e Extensão Rural (ATER), um Plano de Desenvolvimento do Assentamento (PDA) era, então, compilado, baseado nas potencialidades do local e nas aspirações dos ocupantes: daí começava a primeira fase de medir e distribuir os lotes e construir as estradas e casas. Apesar dos atrasos burocráticos e financeiros, isto estimulava a economia local, criando empregos dentro e ao redor dos assentamentos.

Foi assim que Arlito, trabalhando como pedreiro nas casas novas do assentamento Rosali Nunes, teve sua primeira experiência deste novo mundo. Com sua memória infantil do despejo de Limpanzol e, depois, do enfrentamento na Toca de Onça, voltou de Rosali Nunes já como militante incipiente do Movimento. Vinte e cinco anos depois do despejo original, Rumo ainda era uma encruzilhada entre a proletarização os sonhos de recamponização. Da geração de Arlito, alguns dos seus primos secundários por parte dos irmãos da sua avó, Dona Maria, já haviam se mudado para o município vizinho de lbicoara, onde trabalhavam como mão de obra nos cafezais, inicialmente como migrantes, mas, agora, definitivamente, sem 
qualquer expectativa de voltar para Rumo ou para a terra. Outros destes primos secundários, principalmente os mais velhos, continuavam suspensos naquela encruzilhada, vendendo dias de trabalho, mas ainda preferindo caçar um pedacinho de terra para arrendar, como Antônio Miguel, na serra. Porém, em contraste, os pais e cinco tios de Arlito e quase todos os seus filhos, primos dele, aguentavam como o eixo da pequena, mas resistente, comunidade da Toca da Onça, ainda liderados pelo velho Zé Francisco. Para aqueles jovens, a vida cada vez ficava mais difícil, dada a escassez da terra da comunidade, limitada às 400 tarefas concedidas depois do enfrentamento de 1981, já trabalhavam mais no ganho do que nas roças. A situação era igual, numa escala maior, na Colônia, entre os integrantes da mesma segunda geração, muitos deles veteranos do mesmo enfrentamento, quando buscavam um pedaço da terra em redor da Toca da Onça. Foi nesta rede dos necessitados e familiares que Arlito e seus colegas do Movimento começaram a mobilização, nos fins da década de noventa.

Escolheram a fazenda Brasileia, depois renomeada como o Assentamento Baixão, por dois motivos: primeiro, sua localização estratégica - entre Rumo e Colônia e, segundo, a vantagem de ter uma boa fonte de água, trazida por gravidade de um poço na serra para uma grande caixa d'água, ainda em boa condição, apesar da própria fazenda ter se tornado improdutiva. Era o mesmo fornecimento de água para o gado da fazenda que eu tinha ouvido, tilintando num cano, vinte anos atrás, quando da minha descida da serra, depois de visitar Antônio Miguel.

No último dia de fevereiro 1998, um sábado, às oito da noite, o pessoal já avisado do plano da ocupação se encontrava em Rumo. Pela madrugada do domingo, dezenas de barracas estavam sendo construídas na beira da estrada e ao redor da caixa d'água. Dentro de uma semana, 320 famílias chegaram. Entre os primeiros, ao lado de Arlito, vinham Valdete e seu marido Otaviano, buscando terras não mais para eles mesmos, porque tinham posses na Toca da Onça, mas para as suas filhas casadas, morando sem terra, em Rumo. Nem todos foram logo convencidos: no princípio, o filho de Valdete e Otaviano, Zé Neto, agora com vinte dois anos, afastou-se: acreditava nas denúncias ao MST na televisão. Porém o exemplo teve efeito: no ano seguinte, junto com seus pais, Zé Neto participou nas duas ocupações vizinhas, de Europa e Moçambique, e, depois, de outras seis no município. Em sete anos seriam um total de dez, com 800 famílias assentadas - um terço da população total do município e acima 
da metade da rural. Mais tarde, com seu irmão Leandro, Zé Neto lideraria a renovação do Movimento em Boa Vista de Tupim na outra margem do rio.

Já com oitenta e dois anos, Zé Francisco, participava das reuniões sobre a ocupação de Baixão e, do seu reduto na Toca da Onça, em Iramaia, dava coragem a seus filhos e netos. Quando, no ano seguinte, o Movimento decidiu atuar no município vizinho, de fazendeiros mais resistentes, foi Zé quem sugeriu o primeiro alvo: a fazenda Dadau, cuja compra pelo especulador PMDBista de Salvador havia provocado o enfrentamento e o acordo restritivo de 1981, deixando Toca da Onça insustentável. Depois de criar um pequeno rebanho e de sacar a madeira, incluindo os ipês que Zé me mostrou na minha primeira visita, o novo dono, sempre ausente, havia deixado a propriedade improdutiva. Isso era previsível. O que mais enraivecia Zé Francisco era o roubo das joias do seu 'mundo véio', os ipês de flor amarela. Aqueles ele não mais podia resgatar, mas a terra, sim.

Segundo seu neto Gil, filho caçula de João Preto e, mais tarde, presidente da associação do assentamento Dandara, resultado da expropriação de Dadau, Zé Francisco foi 'a cabeça e alma' do projeto de 'liberar' a fazenda, como ele mesmo dizia. Os mobilizadores da ocupação eram todos seus filhos e netos, liderados novamente por Valdete e sua família. De fato, o processo das ocupações, uma vez lançado, era quase autossustentado, uma maré de ondas sucessivas. Cada ocupação envolvia um número de famílias acima daquele que, depois, caberia no assentamento - 320 no caso de Baixão - enquanto os lotes, medidos depois pelo INCRA e distribuídos por sorteio, eram somente 140. As famílias remanescentes tipicamente se deslocavam para a próxima ocupação. Algumas passaram anos em duas ou três, antes de serem assentadas: era o preço que tinham que pagar pela política do MST, de manter uma pressão permanente, indubitavelmente efetiva, mas pesada, para as famílias acampadas, reduzidas quase a tropas de choque para manter o Movimento.

Na madrugada de 08 de março de 1999, a camioneta arrumada por Zé Neto saiu da Toca da Onça para Dadau, uns oito quilômetros distante, levando a vanguarda dos ocupantes, todos com suas ferramentas e prontos para trabalhar. Apesar de sentir a velhice, Zé Francisco queria acompanhá-los, mas os jovens, ansiosos pela segurança dele, convenceram-no a adiar sua presença. Encontraram a fazenda deserta: seu único empregado era o gerente, morando em Iramaia. Nos dias seguintes, dos quais Zé Francisco sempre recebia notícias, chegaram dezenas de famílias, remanescentes da ocupação de Baixão, sem 
terem conseguido lotes. Juntos, fizeram suas barracas perto da sede da fazenda, e, na beira do rio, abriram roças e plantaram milho e feijão.

Foi nesta fase que Zé Francisco, apesar de estar fraco, conseguiu visitar a comunidade que nascia, já, com o nome da famosa quilombeira Dandara. Gil me descreveu como a alegria de seu avô no local e seu prestígio entre todos os ocupantes deram força para o trabalho deles. Apesar de ele ainda falar do futuro, querendo ver luz elétrica na Dandara e na Toca da Onça, parecia que o velho, então com oitenta e três anos, tinha um sentimento de missão cumprida. Quando faleceu, em agosto do ano seguinte (2000), Valdete e Otaviano e todos os netos ativistas, incluindo Arlito e Zé Neto, estavam fora, assistindo ao IV Congresso do MST em Brasília. Na volta, plantaram um pé de castanha-do-pará perto da sepultura dele no cemitério de Rumo, por ser a árvore que cresce mais alta de todas na floresta.

De fato, faltava mais um capítulo na confirmação de Dandara. Foi no mesmo ano que o governo FHC introduziu a 'lei anti-invasão', ditando que qualquer propriedade ocupada seria excluída da expropriação, ainda que fosse improdutiva. Com base nessa lei, o dono de Dadau conseguiu a reintegração de posse, executada por uns cem polícias armados, que destruíram as barracas e roças. Porém, tanto a polícia como os ocupantes atuaram pacificamente, sugerindo uma mudança de forças e de atitudes: a polícia dava tempo para os ocupantes tirarem seus trens, enquanto estes se afastavam sem resistir, seguindo a estratégia do MST - genuína, senão sempre observada - de atuar só dentro da lei. Daí em diante, em vez das ocupações, armavam-se acampamentos fora das propriedades: neste caso, foi feito um logo na Toca da Onça, encostado à fazenda e apoiado e sustentado pela comunidade inteira. Novamente Valdete tomou a frente para completar a missão do pai. E conseguiu: como a ocupação havia ocorrido antes da lei anti-invasão, a propriedade continuava elegível para ser desapropriada. Com a revelação de que havia passado anos sem pagar os impostos da terra, o dono cedeu. Em dezembro de 2002, o assentamento Dandara foi confirmado com a emissão das posses. Imediatamente, os acampados voltaram a reconstruir suas barracas e replantar as roças, aguardando a implantação da infraestrura pelo INCRA.

Assim que a medição de Dandara mostrou que só dava para 50 lotes, excluindo a metade das famílias acampadas, a resposta por parte da Toca da Onça foi previsível. Mantendo seu papel de recamponizar a região, a comunidade logo lançou mais um acampamento no limite com a Floresta do Rio Una, em plena vista do antigo Limpanzol. Este, 
em breve seria o local e o nome de uma das quatro agrovilas deste novo assentamento. Com quase 20 mil hectares (ou 200 quilômetros quadrados) e renomeado Boa Sorte do Rio Una, seria o maior na Bahia, depois do primeiro, de Angical, estabelecido pelo Primeiro PNRA, cujos líderes eu havia encontrado no escritório do INCRA, em 1989. Com a elaboração do Segundo PNRA, seguindo a eleição de Lula em 2002, a dinâmica da reforma agrária parecia renovada. Na Floresta, a única resistência, pelo lado dos fazendeiros locais, foi de esvaziar os pneus da viatura do INCRA, para atrapalhar a vistoria. Esta revelou tanto desmatamento ilegal - o motivo, na realidade, de muito investimento subsidiado na região - que a indenização das benfeitorias foi bastante reduzida pela multa consequente. Em maio de 2006, na cerimônia da emissão de posse - ocorrida na sede do município, quando talvez devesse ter sido em Limpanzol - Valmir Assunção, líder estadual do MST e deputado federal do PT muito votado na região, prometeu um investimento impressionante de $\mathrm{R} \$ 16$ milhões para o assentamento nos dois anos seguintes. Com a reeleição dele e de Lula em novembro, e com Jaques Wagner do PT como governador da Bahia, muito daquele investimento chegaria. Portanto, mais relevante que a soma, havia a questão qualitativa: como seria investida, visando que futuro para os assentados?

Cansada da luta, e, da mesma forma que seu pai com Dandara, Valdete não viveu o suficiente para ver a emissão de posse do novo assentamento. Porém, chegou a saber que, agora, entre os netos do seu pai, não havia ninguém sem acesso à terra. Quando faleceu, em 2004, ainda jovem, foi enterrada perto de seu pai, debaixo do pé de castanha-do-pará, que já ia alto.

\section{Retorno a Limpanzol: o caminho lento para a cidadania}

Depois de reencontrar-me com Arlito, percorri os três assentamentos da Bacia do Rio Una, associados com a história de Limpanzol e Toca de Onça. Em Baixão e Dandara, testemunhei a construção lenta de vidas novas cheias de esperanças e dificuldades. Na Boa Sorte - onde andei, como passageiro, de motocicleta com os netos de Zé Francisco encontrei com famílias ainda lutando para se estabelecer, os novos e largos espaços gerando um sentido igual de liberdade e de incerteza. No final, como antigamente, fiquei hospedado na Toca da Onça, refletindo sobre tudo que eu havia visto.

Minha impressão principal foi de como a viabilidade dos assentamentos variava. Dos três, Baixão parecia o mais estável, não somente por ser o primeiro, mas graças a dois fatores 
distintos. Havia a disponibilidade da água de boa qualidade, vinda da serra. Fluindo por gravidade, vinha sem os custos de energia que os outros assentamentos tinham que pagar para puxá-la. Assim, cada família contava com um pequeno lote irrigado. A produção de verduras, tradicionalmente arriscada pela irregularidade das chuvas, havia subido e se tornado mais estável. O outro fator favorável derivava de um convênio do Programa Nacional de Produção e Uso do Biodiesel (PNPB), celebrado entre o INCRA, o MST e a Petrobrás, que fornecia mercado e preços garantidos em médio prazo, além de apoio técnico, para a produção de mamona nos assentamentos da Chapada. Com a cooperativa regional do MST como intermediário, Baixão foi um dos maiores participantes no projeto ${ }^{1}$.

Isso se deu, em parte, por causa da disponibilidade da água, mas também pela presença de Arlito como técnico do programa: depois do ginásio e de seu trabalho como pedreiro em Rosali Nunes, ele se formou como agrônomo numa escola técnica do sistema educacional estadual, expandido pelo governo Lula para democratizar o acesso à educação técnica e superior. Bastante resistente à seca, a mamona era, tradicionalmente, o produto comercial mais cultivado pelos pequenos produtores na Chapada, especialmente em Colônia, e também pelos posseiros, como os da Toca da Onça. Sua aptidão também se devia ao fato de a mamona produzir melhor quando plantada em consórcio, principalmente com o milho. Nos assentamentos, os técnicos - simpatizantes do MST e empregados da Petrobrás intensificaram tal prática, pesquisando as variedades mais apropriadas para ambas as culturas nos solos locais. O milho, em sua maior parte, era usado para o autoconsumo humano, ou para alimentar a pequena criação, como galinhas, criadas e consumidas pelas famílias, numa escala agora bastante ampliada.

O sucesso do projeto resultou desta interação dinâmica, primeiro entre o conhecimento local e a inovação técnica, e segundo, entre a subsistência e a produção para o mercado. Uma situação bastante distinta da que havia ocorrido na Toca da Onça, nos anos oitenta, quando, pela primeira vez, com a terra titulada, Zé Francisco e outros haviam tido acesso ao crédito bancário, que tomaram para evitar a necessidade de trabalhar fora, nas

\footnotetext{
1 Lançado pelo governo Lula em 2004, o PNPB reformulou o programa nacional de biodiesel para incluir o objetivo social de ampliar o emprego, produtividade e renda dos agricultores familiares, por meio de incentivos tanto para eles como para os produtores de biodiesel para a Petrobrás. No Nordeste semiárido, foi um dos programas mais exitosos do governo Lula para o setor familiar: teve um impacto positivo, não somente na renda e emprego, mas também no cooperativismo (BRASIL/MDA 2010; MATTEI, 2010)
} 
fazendas. Porém, naquela época, os bancos só ofereciam linhas de crédito monoculturais, para plantar um produto comercial, sem consórcio e com o produto escolhido pelo banco, na base do seu valor atual no mercado. No caso da Toca de Onça, o produto era o algodão - sem qualquer consideração quanto à sua viabilidade em termos de fatores locais, como o conhecimento da cultura ou a qualidade da terra. Enquanto aptas para o agronegócio, produzindo monoculturas com insumos industriais, sem referência à natureza, tais normas dos bancos - enfim, do capital financeiro - não se enquadravam nas prioridades dos agricultores familiares. Estes precisavam do direito de decidir como utilizar seus próprios fatores de produção - não industriais, mas humanos e naturais - diversificando as culturas, direcionando-as, não somente para o mercado, mas também para reproduzir estes mesmos fatores de produção: ou seja, para sustentar a família e pequenas criações, conservar a qualidade do solo e recursos hídricos etc.

Naqueles anos oitenta, o crédito para os habitantes da Toca da Onça era menos um projeto comercial e mais um meio de viver, enquanto trabalhando para eles próprios, plantando e cuidando as roças. A solução, meio cômica e meio trágica de alguns sabidos, era simplesmente ignorar a regra monoculturista do banco. Plantavam em consórcio e principalmente para autoconsumo, em formas determinadas por seu próprio conhecimento e cultura camponesa, diversificando para minimizar os riscos. Para prevenir as vistorias pelos técnicos do banco, inventavam que havia cascáveis nas roças. Depois da comédia, no entanto, podia seguir-se a tragédia de ter que pagar ao banco através da delapidação das matas para fazer lenha para vender ou, simplesmente, perdendo-se a terra.

No desenho do projeto com a Petrobrás, os dois imperativos, o familiar e o comercial, foram integrados ao invés de contrapostos. Além disso, estabeleceu-se a garantia do preço da mamona para um prazo definido, mais que dobrando aquele pago pelos atravessadores nas feiras locais, que tradicionalmente colaboravam para baixá-lo. O resultado, nos anos seguintes, foi um aumento dramático da produção e da renda dos assentados, limitado apenas pelas vicissitudes do clima, cujos efeitos nem a irrigação de Baixão eliminava: a seca podia reduzir a safra da mamona pela metade, e até mais, no caso das culturas menos resistentes, como o feijão. Nos anos bons, tinham a vantagem de servir tanto para vender como para o autoconsumo, correspondendo ao duplo papel previsto para a agricultura familiar dos assentamentos, de fornecer comestíveis tanto para o mercado local como para os produtores. Nos lotes grandes, duma média de quinze hectares, sem irrigação, mas 
algumas com água depositada em tanques de cimento e a opção de levar o gado para beber no rio, a maioria de famílias também criava uma média de dez cabeças de corte, vendendo uns dois ou três por ano. Algumas famílias também tinham gado leiteiro, produzindo só para autoconsumo. Por falta de apoio efetivo da ATER, um projeto do Programa de Fortalecimento Nacional da Agricultura Familiar (PRONAF) de criar gado leiteiro para a produção comercial havia falhado, deixando os assentados desmoralizados e inadimplentes (MURITIBA, 2008; SANTANA DOS SANTOS, 2014). Foi somente mais tarde que esta desilusão foi retificada pelo projeto mais apto de Petrobrás, formulado sem intervenção da ATER. A experiência indicava o grau de cuidado necessário para identificar projetos viáveis para o assentamento, fator que tipicamente faltava no planejamento unidimensional de cima.

Somando-se os resultados de todas estas atividades, um estudo de Baixão, por Muritiba (2008), sugere que, além do bem-estar das unidades familiares e da autonomia implícitas no trabalho por conta própria, sua renda, em termos reais - incorporando o valor dos itens de autoconsumo - comparava favoravelmente com aquela do trabalho assalariado fora do assentamento. A proporção da renda total que derivava daquilo correspondia a menos de $10 \%$, derivando principalmente do trabalho sazonal nos cafezais e no distrito de Cascavel, em Ibicoara, onde vários agronegócios, incluindo uma empresa multinacional, produziam frutas e verduras, com a vantagem subsidiada de serem irrigados pela represa Apertador, acima de Itaeté. Se este grau de autonomia econômica de Baixão fosse generalizado no setor reformado, reduzindo o excesso de mão de obra disponível ao setor empresarial, teria o efeito de aumentar os salários e, assim, beneficiar a economia local como um todo. Porém, para ser sustentável, tal autonomia dependeria de um aumento de produtividade nos assentamentos pelo menos igual ao crescimento demográfico, para absorver os jovens: até no caso favorável de Baixão isto já estava em dúvida, segundo Arlito, enquanto, nos outros assentamentos, parecia um objetivo remoto. No vizinho assentamento Europa, a proporção da renda, ainda oriunda do 'ganho', chegava perto dos 50\%. Nestes dados apareciam os primeiros sinais das limitações na execução da segunda reforma agrária (PNRA 2), lançada por Lula em 2003, em resposta ao surto de acampamentos e em meio às esperanças de sua eleição.

A força relativa de Baixão parecia se dever, pelo menos em parte, à disciplina imposta pelo MST, que se opunha ao trabalho fora do assentamento e insistia em que todos os 
assentados morassem lá mesmo, na agrovila, sob pena de perda dos lotes, caso não aceitassem tais condições. Enquanto isto fortalecia o sentido de identidade na comunidade, era evidente que tais políticas estavam longe de ser unânimes e, às vezes, funcionavam como divisórias. Chegaram ao ponto de causar o êxodo de uma minoria significante dos assentados e até prejudicar as raízes da solidariedade social, nos próprios laços familiares: várias famílias sentiam falta de parentes ainda morando em Rumo, onde alguns dos seus filhos ficavam para estudar, depois da 4 a série, disponível no assentamento. A preferência do MST pela eleição dos dirigentes da associação como 'chapa única', aprovada pelo Movimento, tampouco agradava a todos: chegou ao ponto de um militante, candidato à presidência, e sua chapa sofrer oposição e perder. Também havia reclamações sobre militantes de fora que influíam, mas raramente apareciam no assentamento. Parece que foi este sentido de um mandonismo externo que havia levado o MST a perder sua liderança em um assentamento chave, Rosali Nunes, o primeiro e maior de Itaeté. Até certo ponto, isto reforçava minhas dúvidas originais sobre a possibilidade da interação democrática por parte do MST com os movimentos autóctones e as culturas distintas da Chapada. Porém Rosali Nunes era apenas um assentamento entre os dez no município, que, em conjunto, já incorporavam uns 20\% da sua área e $30 \%$ da população: sem a presença do Movimento, esta transformação nunca teria acontecido.

Entre os assentados, encontrei novamente com Maria e Del, que me haviam hospedado em Rumo. Anteriormente, sem intenções de voltar à terra, acabaram por mudar para Baixão, na esperança de que algum dos seus filhos voltasse: dos cinco, todos tinham migrado para longe. Apesar da mesa de fórmica vermelha não ter sobrevivido ao passar do tempo, a casa nova mostrava a mesma determinação de Maria de que eu lembrava: vencer qualquer obstáculo ao melhoramento da qualidade de vida da família. Com um entusiasmo igual ao dela sobre o interior da casa, Del me mostrou o quintal no fundo, com fruteiras já maduras e verduras, tomates e feijão de corda; os plantios incluíam variedades novas, compartilhadas entre vizinhos. Pensei no contraste entre aquele interesse renovado na natureza e sua resolução amarga, depois do despejo de Limpanzol, de nunca mais voltar a terra. Apesar da seca, a água encanada da serra dava para molhar o quintal: anteriormente, nunca havia verduras sem chuva, enquanto frutas, simplesmente não havia - os supostos donos dos suas posses proibiam qualquer cultura permanente. Ali, finalmente, tinham uma vida sem as pressões cotidianas do passado. Porém, sem filhos e na velhice, era difícil para 
eles trabalharem no seu lote grande. Seu meio de vida principal era a aposentadoria, como no caso de uns 30\% das famílias vizinhas (MURITIBA, 2008).

Esta ausência e o êxodo dos jovens dos assentamentos era uma preocupação crescente, como Arlito admitiu no dia seguinte, no caminho de barro acidentado para o assentamento Dandara. Era ali, entre Rumo e Toca da Onça, que muitos dos seus primos estavam assentados, enquanto sua filha Maíra era professora na escola, que tinha o nome comemorativo do bisavô dela, Zé Francisco. Os pais de Arlito, Joventino e Aura, a filha mais velha de Zé Francisco e Dona Maria, também moravam ali. Hospedaram-me na sua casa modesta e confortável; e, entre os primos de Arlito, quem mais me atualizou sobre Dandara foi Gil, agora presidente da associação do assentamento. Lembrei-me dele entre os filhos de João Preto, o segundo dos seis de Zé Francisco e Dona Maria e o único que, já na década de 6o, foi trabalhar em São Paulo. Ali havia ficado o único dos seis irmãos que aprendera a ler e escrever um pouco: mais tarde, era ele quem escrevia as cartas que Zé Francisco me enviava. Casou-se com uma paulista, voltando depois para Toca da Onça onde criou os cinco filhos, dos quais Gil era o caçula. Quando João faleceu, as quatro filhas mais velhas emigraram para morar com seus parentes paulistas. Porém Gil ficou na Toca da Onça com sua mãe Elena. Ficou, em parte por ser o mais jovem, mas também conscientemente, tendo resolvido fazer sua vida na Chapada. Ouvia as experiências negativas de tantos conhecidos voltando de São Paulo, nesta época, em circunstâncias desastrosas: ordenados retidos por patrões, alegando dívidas desconhecidas; poupanças roubadas no ônibus de volta e, no caso mais chocante, um jovem voltando a Rumo e sendo seguido e fuzilado no mato pela policia federal, como membro alegado de uma quadrilha em São Paulo.

Foi assim que Gil chegou a participar, junto com seus primos e tios, na mobilização e ocupação da fazenda Dadau e sua transformação no assentamento Dandara. Agora, com 30 e poucos anos, como presidente da associação, liderava o processo de negociar e implantar os acordos feitos com o INCRA para desenvolver a comunidade. Porém, conversando e me mostrando as atas da associação, indicava que, apesar da inauguração do assentamento coincidir com o início do governo PT, seguido pelo Segundo PNRA, o progresso de Dandara, desde 2002, havia sido pequeno. Como na Chapada inteira, a seca explicava muito, mas nem tudo. O outro lado era o vazio aparente entre as promessas e programas do governo, e do MST como seu parceiro, referentes à reforma agrária. O impacto das reformas redistributivas - a promessa de Lula de assegurar comida, casa, água e educação para todos os brasileiros - 
era evidente. A destituição absoluta desaparecera e a pobreza era muito menor (CANIELLO, 2016). O direito de acesso a terra foi confirmado. Porém a inclusão, no sentido de criar um futuro seguro, com meios de vida produtivos e sustentáveis para a massa do povo do campo, ainda estava distante.

A agrovila estava situada acima do rio, junto à antiga sede da fazenda e debaixo da ladeira e da estrada para a Toca da Onça, uns oito quilômetros ao sul, onde o rio Una descia. Os lotes estendiam-se na mesma direção, em cada lado da estrada, tanto que os últimos ficavam a uns sete quilômetros da agrovila, no limite com Toca da Onça. De fora, a comunidade parecia bastante ativa: dezenas das cinquenta casas estavam em obras de melhoramentos, financiadas por uma nova linha de crédito do INCRA. A maioria dos agraciados usava o custeio da mão de obra para sustentar a família, enquanto eles próprios faziam a construção; os velhos, como Juventino e Aura, empregavam vizinhos mais jovens, tipicamente parentes, para o trabalho de construção. Assim, quase todo o montante daquele financiamento ficou dentro do assentamento, criando uma economia temporariamente viável. Diferentemente de Baixão, as casas ali eram contíguas e sem quintais, por falta de espaço; um local alternativo mais alto, entre os lotes na beira da estrada e com mais espaço, havia sido preferido por muitos dos associados, mas rejeitado pelo INCRA, para limitar os custos de fornecer água a uma maior distância. Na agrovila havia água encanada, puxada do rio próximo, para uma caixa na ladeira, de onde descia para as casas; porém nos lotes só chegava pagando-se o carro pipa da associação, para levá-la aos tanques de cimento para o gado beber.

A agropecuária era pouca. Nos primeiros anos, Gil explicou, valia a pena pagar o custo do carro pipa, de vez em quando, para suplementar a chuva: além de mamona e milho para vender, ele havia conseguido produzir suficiente mandioca, batata doce e verduras para abastecer a família. Mais tarde, um projeto de pecuária foi financiado pelo PRONAF: depois das cercas e plantio de pasto, em 2010, cada família recebeu quatro matrizes. Apesar do lote de Gil ser distante, tendo motocicleta, aumentou suas quatro cabeças para nove. Porém, de 2012 em diante, a chuva sumiu: com o pasto secando e o custo da água, muitas famílias perderam ou venderam seu rebanho inteiro. Gil ainda criava quatro cabeças, mas isto estava acima da média: tipicamente somente os donos dos lotes mais próximos tinham algumas, por ser mais fácil levá-las para beber no rio. 
Entre as cinquenta famílias de Dandara, situações como a de Gil, jovem, sadio e capaz, eram as melhores. Já com dez anos, a comunidade parecia conviver menos com qualquer visão do futuro e mais com uma combinação de soluções de emergência: a reduzida pecuária, o emprego temporário no projeto de melhoramento das casas e as transferências do estado - o Bolsa Família e a aposentadoria - como no caso dos pais de Arlito. Fora disto, somente havia uns poucos empregos em serviços novos e a opção de trabalho diário nas fazendas, já mais escasso por causa da mecanização, ou nas empresas mais distantes. No caso de Cal, vizinho e primo de Gil, e filho de Antônio e Aninha da Toca da Onça, sua esposa Maria era zeladora da escola, enquanto ele, sem gado ou roça, continuava como diarista: na sua vida econômica, o único melhoramento havia sido a compra, a prestações, da motocicleta, que Ihe permitia voltar para casa à noite.

No dia seguinte foi Cal quem me levou para Toca da Onça, pela estrada entre os lotes, alguns com uma ou duas tarefas de palma para alimentar os poucos e pequenos rebanhos, os outros secos e quase inutilizados. A persistência da associação em pedir água encanada para os lotes ainda parecia longe de ser atendida e financiada pelo INCRA. Só havia um lote diferente dos demais, perto de Toca de Onça, com umas três tarefas de pés de café recémplantados, retos e verdes: pertencia a Pedro Bispo, neto do velho Cil, de outra família antiga de Toca da Onça, conforme me explicou Cal. Ali, mais perto do rio, ele conseguia puxar água para o lote, com uma bomba comprada e mantida por conta própria, para molhar seus pés de café. De qualquer forma, sua situação indicava que, até em condições difíceis, não deixa de haver os sobreviventes por natureza; e que, talvez estes, no futuro, compeliriam os assentamentos e o MST, comprometido ao 'socialismo', a enfrentar uma questão complexa quando os assentamentos fossem 'emancipados', como previsto pelo INCRA, dando títulos aos assentados, o que permitiria a venda da terra. Aceitariam a diferenciação, na forma da acumulação de lotes nas mãos dos agricultores mais empresariais, como Pedro Bispo? Por um lado, isso abriria um caminho para a desigualdade dentro dos assentamentos; por outro, poderia ser o único meio de mantê-los como entidades de produção relativamente pequena, evitando a volta à desigualdade muito maior, de compras múltiplas de fora, por novos especuladores em grande escala acumulativa.

Da Toca de Onça, onde passei os dias seguintes, era Tum, o neto de Antônio e Aninha, que me levava de motocicleta para conhecer a antiga Floresta, agora o assentamento Boa Sorte do Rio Una. Estranhei um pouco entrar sem Zé Francisco neste 'mundão', que, juntos, 
tínhamos passado não sei quanto tempo olhando e discutindo. Com seus quase vinte mil hectares, era dez vezes maior que Dandara. Era ali que os acampados da onda final e maior dos sem terra da região estavam assentados: variavam de veteranos de Baixão, como Val, sobrinho de Dona Maria, até a terceira geração, dos netos dela e Zé Francisco, como Tum e seu irmão, Renato. Sete anos havia passado desde a emissão de posse, em 2006, quando os 16 milhões de reais foram prometidos pelos políticos, principalmente do PT, como Valdir Assunção, depois reeleito como deputado federal bastante votado na região. Estava claro que uma parte daqueles recursos havia chegado, para levantar as casas das quatro agrovilas. Uma delas situava-se no antigo local do Limpanzol, logo abaixo da Toca da Onça, e as outras três - Floresta, Sede Nova e Sede Velha - na parte mais alta. Na Sede Nova, uma escola grande já funcionava, com transporte para os alunos nas dezenas de quilômetros das novas estradas de barro e, como nos outros assentamentos, o fornecimento de energia pelo programa da 'Luz para todos' estava completo.

Porém, além desta infraestrutura, o processo de criar um meio de vida e futuro seguro parecia ainda mais suspenso do que em Dandara, principalmente pela falta quase total de água, a não ser do rio. Para mim, visitante, a cena das mulheres e crianças lavando roupa nas rochas planas, no meio da água rasa e clara, como antigamente na Toca da Onça, era pitoresca: para elas, como no passado na Toca da Onça e no Rumo, para Loura, era um trabalho do dia inteiro, compensado por conversas, risadas e banhos no rio, mas pesado. Para água doméstica, ali, o INCRA apenas começava a instalar as cisternas brancas de 16000 litros, algumas de cimento e outras de plástico, prometidas para cada família rural por um dos programas chave do Governo Lula ('Água para todos') no semiárido do Nordeste. Quando encontramos com Val, o sobrinho de Dona Maria, na Sede Nova, ele me informou que, até então, as cisternas só tinham chegado para cinco famílias das cento e cinco residentes na agrovila. Aliás, diferentemente da água encanada em Dandara, o enchimento das cisternas dependia ou da chuva, captada nos telhados, ou do carro pipa. Por enquanto, tanto ali como também na Toca da Onça, os carros pipas do Exército enchiam as cisternas de graça. Porém nem Val, nem sua filha assentada perto dele, sabiam quando suas cisternas chegariam.

Com tanto espaço disponível, nos fundos das casas havia quintais amplos, como em Baixão, mais apropriados que os lotes, distantes para o plantio e colheita dos produtos de consumo doméstico do dia em dia e para ensinar as crianças a valorizá-los e cultivá-los. Muitos deles já estavam cercados: mas, sem água, não produziam. Segundo Val, o solo era 
razoável. Nos anos bons de chuva, de 2006 em diante, produziu-se bastante, tanto no lote como no quintal; mas, nos anos recentes, sem água ou chuva, não se havia colhido nada. Quanto à pecuária, algumas famílias ainda tinham umas cabeças; aqui eram criadas soltas, ao invés de guardadas nos lotes, para poderem beber do rio, curvando em redor do sul do assentamento. O problema era que essa prática se chocava com a obrigação ambiental de manter uma reserva florestal inexplorada, que incluía a beira do rio. Antes do cumprimento dessa condição, o início de um projeto do PRONAF para cercar os lotes não podia ser autorizado. Porém a própria presença do gado se devia, em primeiro lugar, à longa demora por parte do INCRA, desde 2006, em iniciar qualquer projeto: mais uma vez, a inércia da burocracia estatal distante foi o obstáculo principal à mesma agricultura familiar que o governo teoricamente promovia.

Para muitas famílias, esta falta de oportunidade dentro do assentamento e sua distância forçavam os homens a ficarem fora para trabalhar, deixando as mulheres e crianças sozinhas e pouco ocupadas, a não ser em apanhar água. A paisagem, com o rio embaixo e a serra a Oeste, e o espaço sem fim em redor das pequenas casas brancas, deu-me a sensação de um novo mundo pastoral, faltando apenas as árvores majestosas que Zé Francisco sempre lembrava: os ipês, paus-ferros e jatobás, todas saqueadas pelos antigos donos. Porém, em seu aspecto humano, o futuro incerto do assentamento e a sua história pregressa, criavam uma mistura estranha de esperança e tristeza, acentuada pelo duo de Val e Tum como assentados distintos, mas representativos. Para Tum, com vinte e poucos anos, ainda morando com seus pais na Toca da Onça e estudando em Iramaia, Boa Sorte era um ponto de partida entre os vários disponíveis à nova juventude; para Val, com mais de sessenta, era o único ponto de chegada, depois de uma vida longa de lutas, gravadas nas linhas do seu rosto bem-humorado, debaixo dum antigo boné vermelho do MST. Tum, nascido no povoado de Trindade, criado em Limpanzol e despejado dali para Rumo, havia passado a juventude trabalhando com seus irmãos nas condições ásperas dos cafezais da serra alta; porém, enquanto os outros ficaram ali, ele voltou para Rumo e daí participou na ocupação de Baixão, esperando conseguir um lote. Sem ser contemplado no sorteio, seguiu para a ocupação de Dandara onde, depois de mais dois anos, novamente caiu fora no sorteio e seguiu para o acampamento da Boa Sorte, onde, finalmente, conseguiu seu lote. Apesar do pouco que the era fornecido e de suas dúvidas quanto às lideranças do MST, por causa das falhas do assentamento, que muitos compartilhavam na nossa conversa na Sede Nova, ele parecia 
filosófico, senão contente. Para Tum ainda havia mais tempo: por enquanto, além de estudar em Iramaia, tornou-se o sucessor de Arlito, como professor da escolinha na Toca da Onça, tendo o lote para seu futuro.

Quanto à própria Toca da Onça, eu imaginava que teria se transformado em uma comunidade apenas de velhos. Não era assim. Dos jovens com lotes em Boa Sorte, mas sem meios de desenvolvê-los, como Tum e Renato, Bebete de Zelito e os gêmeos Jean e Jovanio, caçulas de Otaviano e da finada Valdete, vários ainda moravam com seus pais, para ajudá-los nas roças da Toca e estudar em Iramaia. Alguns dos outros, já morando no assentamento, deixavam seus filhos pequenos com os avós durante a semana, para frequentarem a escola. Assim, para a maioria, os laços familiares continuavam como o eixo da sua vida social, com uma força igual àquela que eu havia sentido, duas gerações antes, no nosso primeiro encontro, naquela noite de candeeiros em 1975, no Rumo.

O ritmo do dia do povoado tampouco havia mudado muito, além do conforto transformativo dos programas da água e da luz para todos. O dia ainda começava com o canto do galo, hoje um canto muito maior e sustentado pelas respostas nos assentamentos vizinhos, primeiro na Boa Sorte e daí para os outros, a Oeste, uma música circundando o mundo camponês, e insistindo na sua força, para voltar com o próximo sol nascente. Se algum músico do MST procurasse uma toada emblemática para o Movimento, devia ser esta, uma resposta nordestina ao trem caipira de Villa-Lobos. Depois, veio o som do povoado acordando, ainda com música de sanfona nos rádios de casa em casa, recordativa de Luiz Gonzaga, e seguido pelas saudações para quem passava para trabalhar na roça: apesar da falta de chuva, com menos demanda pela pouca terra do povoado, a terra cansava menos e ainda dava um pouco de mandioca e mamona. Da escola, o som das crianças cantando boiava no calor do meio-dia. De tarde, quando resfriava, nunca faltavam jogadores para o campo de futebol, agora com palmeiras maduras em redor para sombrear os espectadores, avôs e netos novos no lugar de Zé Francisco e os seus. Apesar de seus horizontes se terem ampliado, os jovens como Tum e Renato ainda se identificavam fortemente com o povoado: uma tardinha, insistiram em levar-me para a gruta, para além do campo, onde, anualmente, no primeiro fim de semana de agosto, comemoravam a fundação da comunidade.

Era como se os assentados oriundos da Toca da Onça houvessem rejuvenescido o povoado. Uma noite, na escola, houve um evento onde tirei algumas das minhas fotos mais expressivas da comunidade. Por acaso, naquela mesma manhã, Otaviano, com tristeza nos 
olhos, havia me mostrado a carteira de identidade da finada Valdete, guardada cuidadosamente. Entre os detalhes no documento havia um termo em que a falta de respeito do estado para uma das suas cidadãs me parecia brutal: 'analfabeta'. Hoje, esta falta estava sendo corrigida por seus novos cidadãozinhos. O evento na escola havia sido um curso de alfabetização de adultos e velhos, ministrado pelos jovens: as fotos eram das mãos das crianças guiando as dos pais e avôs, para escrever seus nomes.

\section{Futuros a serem construídos 'de baixo'? Campesinismo, 'modernidade' e agrosustentabilidade}

Foi ali, na tranquilidade do povoado semeadura dos assentamentos, que eu tive tempo para refletir a pergunta óbvia, mas complexa: que futuro poderiam ter?

As transformações das vidas de Zé Francisco e seus herdeiros, apesar de locais, pertenciam àquelas da metade do mundo virada de cima para baixo pelo mesmo tsunami que começou com a chegada do neoliberalismo global, subindo a BR 242 naqueles anos dos anos setenta, reforçado nos anos oitenta pela crise da dívida externa, imposta pelos países no Norte aos pobres do Sul. Em seguida, depois do choque dos despejos, a destituição consequente e as migrações 'pelo meio do mundo', não só na Bahia, mas no país, no continente e no 'Sul' inteiro, surgiu a resposta comum: a resistência dos povos desenraizados pela imposição do agronegócio no lugar dos seus 'mundos véios', tecidos das relações com a natureza.

Desde os Zapatistas de Chiapas até o Sendero Luminoso de Peru, novos movimentos com bases camponesas e indígenas desafiaram os regimes neoliberais e seus conceitos de uma agricultura moderna. No Equador e na Bolívia, chegaram ao ponto de eleger governos propondo um padrão contrário - a 'Via Campesina' - baseado no poder e na produção neocamponesa, para assegurar a soberania alimentar e a sustentabilidade, ao invés da subordinação ao agronegócio transnacional e predatório do capitalismo financeiro, espalhando a grilagem e a tecnologia da 'revolução verde' pelo mundo inteiro. Isto tudo se relacionava, não somente com modelos agrícolas e identidades nacionais: a questão mais ampla era o tipo de sociedade desejável no século novo, nacional e globalmente. Seria polarizado, tanto social como ecologicamente, ou integrado nestes dois níveis entrelaçados das relações entre pessoas e povos, e destes com a natureza? 
Apesar das diferenças entre estes casos e o brasileiro, tais acontecimentos chegaram, por intermédio do Movimento internacional 'Via Campesina', a ter uma influência forte sobre a visão do MST. Assim, nos anos noventa, o movimento mudou sua perspectiva original de conduzir os sem terra numa direção soviética (trabalhista, produtivista e coletivista) e redefiniu-os como um neocampesinato, portador da sustentabilidade. Como consequência, seu $4^{\circ}$ Congresso, em 2000 (ao qual a delegação da Chapada assistiu), adotou a agroecologia como o novo paradigma de produção nos assentamentos do Movimento, como continua até hoje (BORGES, 2009). Porém, como Cristobal Kay observa, no final, os outros movimentos neocamponeses e seus governos radicais tiveram pouco impacto na dominação do agronegócio global; e, conquanto suas reformas sociais e redistributivas (como as dos governos de Lula) tenham reduzido a pobreza, havia também o paradoxo destas ações serem financiadas, em grande parte, pela renda fiscal do setor agroexportador, cuja expansão continuava (KAY, 2014) $)^{2}$.

A situação da Boa Sorte indicaria um declínio semelhante na possibilidade de um novo equilíbrio de forças no campo? Se não de uma plena 'via camponesa', pelo menos de um elemento camponês suficientemente amplo, forte e apoiado pelo estado para transformar, não somente o acesso à terra, mas também os meios de vida dos assentados, numa forma sustentável para as gerações futuras? Minha impressão não era otimista: fora da estabilidade resultante no curto prazo das medidas redistributivas de Lula, a economia dos três assentamentos que eu havia visitado dependia sempre mais da pecuária extensiva, tradicional na região. Para os primeiros assentados, sua participação nesse modo de ser já era melhor que a privação do passado, mas estava longe de criar meios de vida sustentáveis para a próxima geração e de definir um papel distinto para a agricultura familiar na sociedade do futuro. Para isto, seria necessário aumentar e diversificar a produção de excedentes para além do consumo familiar, e encontrar meios de agregar o valor deles, para melhorar tanto as rendas como, também, o mercado e economia locais. Mas, de que forma? Com que 'modernismo'?

\footnotetext{
2 Apesar do recuo dos movimentos camponeses, o debate sobre a viabilidade da 'via camponesa' para os países do 'Sul' continua, com um desacordo tipicamente entre analistas do 'Norte', inclusive de simpatizantes do campesinato como Bernstein (2014), negando sua capacidade para gerar a transformação social, e os protagonistas do 'Sul', que continuam a afirmá-la (MOYO ET AL, 2013).
} 
Os resultados que eu estava vendo, culminando na incerteza em Boa Sorte, pareciamme uma medida das limitações das três respostas dominantes a estas perguntas entre pensadores e analistas do assunto, cada uma oposta às outras e com seus próprios conceitos chave. Destes conceitos, o primeiro era o de agricultura familiar. Originado no governo de Cardoso e refletido na primeira geração dos assentamentos, como Baixão, foi mantido no tempo de Lula, pelos mesmos meios do MDA (Ministério de Desenvolvimento Agrário) e do PRONAF; mas, agora, havia sido reorientado na direção de um segundo conceito distinto, o de 'camponês', pela influência do MST na política agrária. Essa inflexão foi contemporânea com a segunda geração de assentamentos, como Dandara e Boa Sorte. A terceira resposta veio, mais tarde, de um grupo de pesquisadores, principalmente da Empresa Brasileira de Pesquisas Agrícolas (EMBRAPA), que eu chamaria dos '7-tesistas' ou 'tecnificadores'. O conceito central dessa posição é de que o único futuro viável para os pequenos produtores no 'novo mundo' da agricultura brasileira (e global) estaria em adotarem a mesma tecnologia 'moderna' e a mentalidade capitalista (que eles nomeiam neste contexto de 'pequenoburguês') do agronegócio de grande escala3.

Implícitas nestas três respostas há percepções conflitantes de duas questões fundamentais: de um lado, a natureza da 'questão agrária'; e, do outro, a identidade dos pequenos produtores do campo no contexto brasileiro. Na época de Cardoso, a questão agrária foi vista como algo já resolvido pela modernização de cima: tratava-se de uma questão essencialmente econômica, de como reconciliar a estrutura agrária com a transição ao capitalismo industrial, já cumprida. Quanto aos pequenos produtores, sem importância num passado dominado pelo latifundismo, a não ser como produtores de subsistência, e, agora, pelas ocupações de terra atribuídas à influência do MST, constituíam uma questão social, bem secundária ao apoio principal do governo para os grandes produtores. A solução (nesta fase ainda neoliberal, mas mais madura e sofisticada do que na presidência de Collor de Mello) foi incluí-los como um 'sujeito novo', denominado 'agricultores familiares', no

3 Alguns dos autores e textos mais influentes entre os muitos em cada uma destas perspectivas são: Abramovay (1998) e Graziano da Silva (1996), no caso da 'agricultura familiar; e da 'campesinista', Wanderley (2004). Apesar de seu uso recorrente do termo 'camponês, Souza Martins (2013) se distingue enfaticamente da tendência política campesinista (e do MST), seu enfoque teórico principal (e, a meu ver, definitivo) estando na questão agrária. Os '7-tesistas' são representados principalmente por Campos e Navarro (2013) e Buianan et al (2013). 
mesmo novo modelo agrícola, dependendo de insumos industriais para produzir os alimentos requeridos pelo mercado interno. Assim, sua dinâmica inerente, de produzir alimentos para o consumo familiar de subsistência, seria integrada com a dinâmica 'moderna' das exigências do mercado. Foi nesta expectativa que o governo Cardoso lançou o PRONAF, para estimular a pequena produção mercantil, junto com uma volta à redistribuição da terra, suspensa desde os anos oitenta.

O equívoco desta política (além de acelerar mais do que abrandar as ocupações) era tratar tais produtores familiares como um grupo homogêneo. Enquanto o desenho do PRONAF poderia ter sido apropriado para os pequenos produtores do Sul, tradicionalmente mais orientados para o mercado, o mundo dos novos assentados do Nordeste era diferente: historicamente mais excluídos e desestabilizados pela escravidão e o latifundismo, demandavam medidas sensíveis a estas diferenças e adaptadas às realidades locais. Estas incluiriam: a fraqueza regional do sistema educacional, a subordinação dos produtores a mercados locais oligopolistas e, sobretudo, o impacto da seca e da degradação ambiental deixada pelos latifundiários e especuladores mais recentes.

Na ausência de tal sensibilidade para com as variações regionais, a aplicação do PRONAF correspondia às prioridades e visão não tanto dos assentados, mas especialmente dos técnicos da ATER e dos bancos envolvidos. O primeiro projeto no Baixão, por exemplo, parecia com aqueles da Toca da Onça nos anos oitenta, predestinados a falhar por estarem distanciados das prioridades e dos recursos da comunidade. Uma década depois, parece que nada havia sido aprendido com as experiências anteriores pelos profissionais tipicamente urbanos e ainda presos à cultura de planejamento, financiamento e assistência técnica preconcebidos e administrados de cima para baixo (SANTANA DOS SANTOS, 2014). Voltado para a criação do gado, o projeto correspondia a um sonho dos assentados: o problema foi que a 'linha do crédito' do Banco do Nordeste local era restrita ao gado leiteiro, demandando a compra de rações especiais de fora e exigindo cuidados dos animais desconhecidos pelos assentados, cuja experiência estava limitada à criação de gado solto para corte, tradicional na região. Por falta de pasto nos anos de seca, quando os leiteiros chegaram, muitos morreram e os outros foram vendidos, deixando a maioria dos assentados desmoralizados e endividados, e, assim, inelegíveis para mais empréstimos do PRONAF.

Outro projeto, para a produção e venda de farinha à Companhia Nacional de Abastecimento (CONAB), falhou por causa de um aspecto igualmente exógeno: a forma da 
farinha exigida pelo CONAB era incompatível com as técnicas das casas de farinha locais (MURITIBA, 2008). Foi somente quando o convênio com Petrobrás teve mais sucesso em integrar os fatores internos e externos em redor do aumento da produção de mamona que houve um resultado mais positivo. A implicação é clara: a importância de planejamento 'de baixo' e específico à natureza da região e da comunidade.

Teoricamente, o pensamento dirigente mudou, no governo Lula, para conceitos mais radicais, tanto da 'questão agrária' como, também, da identidade, passada e futura, dos pequenos produtores. A 'questão' adquiriu um sentido mais amplo, como efeito de várias outras questões, tanto sociais como econômicas, intensificadas, ao invés de terem sido resolvidas pela modernização 'de cima para baixo': a tarefa era enfrentar as novas formas de desigualdade, a exclusão e o descuidado meio ambiente, gerados pelo modelo vigente.

Tanto o público a ser atendido, como os motivos pelo direito de acesso à terra e de permanência nela agora iam muito além da necessidade - ainda reconhecida - de melhorar a produção familiar. Entre o novo público havia os povos tradicionais, quilombolas e indígenas, com seus direitos afirmados na Constituição de 1988, mas ainda ameaçados e assaltados pela grilagem. O acesso à terra não era apenas um direito econômico, mas igualmente uma afirmação da identidade e diversidade etnocultural e regional. Isto seria reconhecido numa nova forma de planejamento pelo MDA, com os 'territórios de identidade', somando municípios vizinhos com características semelhantes e visando ao planejamento 'descentralizado e participativo'. Destes, alguns foram posteriormente redefinidos e priorizados como 'territórios da cidadania', em regiões onde a reforma agrária foi concentrada: entre elas, na Bahia, estava a Chapada Diamantina (ROCHA, 2010).

Quanto aos próprios agricultores familiares, ao invés de meramente participarem no sistema agrícola vigente, agora - pelo menos no pensamento do MST, atuando dentro do governo - tinham o papel de transformá-lo. Este destino derivava da noção de eles serem, ao invés de meros 'sujeitos novos' e secundários da modernidade mercantil, um 'campesinato', integral à história agrária brasileira e à sua futura transformação, com suas qualidades de classe contrárias àquelas do agronegócio capitalista. O primeiro passo concreto neste caminho ao socialismo (para o MST) seria a agroecologia: no planejamento do MDA da época, esta teve um dos perfis e orçamentos principais, comparáveis aos do 'desenvolvimento territorial'. 
Porém, a palavra mais importante de tudo isto é a primeira: 'teoricamente'. Num novo século, com seus problemas exponenciais derivando não da baixa produtividade, mas, ao contrário, da desigualdade e insustentabilidade, as preocupações dessa nova visão são claramente as mais 'modernas'; ou melhor, reconhecem a necessidade de repensar o 'moderno' numa direção mais contemporânea e justa. Porém sua relevância deve estar sujeita aos mesmos critérios não meramente teóricos, mas substantivos, de qualquer outra perspectiva: existiria mesmo um tal campesinato, tão distinto do 'novo sujeito', mas igualmente genérico e, assim, homogêneo e com o destino histórico proposto pelos 'campesinistas'? E, sobretudo, depois dos oito anos de Lula, seguidos pelos cinco de Dilma, com a parceria do MST, onde estariam os resultados concretos das políticas oriundas desta nova perspectiva?

$\mathrm{Na}$ Chapada, para os assentados, com sua necessidade central de novos meios de vida viáveis, tais resultados pareciam escassos. Quanto à agroecologia, seja qual for seu disputado potencial, a luta para a sobrevivência dificilmente se combina com as aspirações de longo prazo implícitas nesse ideal: a despeito de todo o esforço e sucesso de alguns produtores, comunidades e projetos agroecológicos, bem como linhas de produção sofisticadas e exitosas, concebidas inclusive por técnicos do MST, tais casos são relativamente raros e concentrados no Sul do país, onde encontram mercados principalmente urbanos e da classe média. Isto não os desvaloriza. Só indica que estão longe de responder às necessidades da maioria, e, ainda menos, de constituir um passo para um socialismo com o qual os privilegiados têm mais tempo para ficar sonhando. Assim, parece que os resultados escassos da parceria do MST com os governos PT não se explica simplesmente como uma acomodação com o superpragmatismo de Lula, comprometido, na realidade, com o agronegócio e grandes proprietários; sugerem, também, uma sinergia entre o burocratismo inflado do estado, pouco mudado pelo PT, e a prioridade excessiva da ideologia na cultura do próprio MST.

$\mathrm{E}$, quanto à terceira proposta, do grupo que chamo os '7-tesistas' ou 'tecnificadores? Vale a pena notar que, apesar de um estilo às vezes arrogante nas suas críticas aos conceitos de 'agricultura familiar', 'campesinato' e 'agroecologia', esses analistas são, em princípio, simpatizantes da pequena produção rural. Porém, para eles, tais conceitos, formalmente vigentes no MDA do governo Lula, junto com a noção completa de reforma agrária, são anacronismos sentimentais e perigosos, obstruindo a única saída viável para os pequenos 
produtores e, também, para o campo não se transformar em um mero fator de produção agrícola em grande escala, vazio de qualquer presença humana, no estilo 'Argentino'. A saída, segundo eles, seria os pequenos produtores se converterem inequivocamente em pequenas empresas tecnificadas, emulando a forma supostamente responsável pelo sucesso produtivo dos grandes: nisto seriam dirigidos por uma nova 'sociabilidade capitalista', priorizando valores 'pequeno-burgueses' - mercantis e acumulativistas - acima dos familiares.

'Agricultores familiares', 'camponeses', 'pequeno-burgueses' e, ainda, 'pobres do campo', nos discursos de Lula - os que buscam meios de sobreviver no campo estão bem abastecidos com denominações exógenas: só que não podem plantá-las nem comê-las. Os 7-tesistas insistem que são os únicos analistas realistas. De fato, o quadro que eles apresentam, da extrema precariedade da grande maioria dos milhões de pequenos estabelecimentos rurais, ainda que desatualizado por derivar do censo agropecuário de 2006 (o mais recente), parece muito mais próximo da situação ainda precária de tantas famílias assentadas do que os cenários idealistas dos programas do MDA e do MST. Têm, além disso, o mérito de sugerir estudos empíricos e locais, na procura de opções mais substantivas. Porém, seus argumentos negligenciam aspectos importantes. A crítica mais concreta, neste caso, é que os argumentos derivam de uma visão tão partidária do sucesso do agronegócio e sua tecnologia 'moderna', que distorcem um fator chave: o grau em que o sucesso produtivo da soja, acima de tudo, depende do aumento não da área, mas da sua produtividade, como eles insistem. Mattei (2013) mostra como isto é exagerado e aparentemente preconcebido. No aumento da produção da soja, a expansão territorial do agronegócio também tem sido importante.

Isto coloca em questão uma 'tese' chave dos 7-tesistas em insistir que a questão da terra, e, assim, da reforma agrária, está ultrapassada. No entanto, frente ao argumento de que a terra não tem mais importância em comparação com a tecnologia, como explicar a gula sem fim do agronegócio para grilar áreas sempre maiores, e as medidas do atual governo Temer para legitimá-la (CUNHA, 2017)? Se o agronegócio tecnificado ainda precisa de tanta terra, por que o setor reformado não precisaria de mais? A resposta implícita 7-tesisista - de que isto apenas expandiria a pobreza de famílias com terra improdutiva - ignora a alternativa: aumentar o setor contribuiria favoravelmente ao seu peso demográfico e consequentemente - à sua capacidade de pressão política, em condições democráticas, para procurar soluções e recursos para melhorar sua produtividade. A falta é desta democracia. 
As deficiências da visão unidimensional dos '7-tesista' vão mais longe: no nível econômico, onde fica a noção de 'valores futuros' em relação aos notórios custos 'externos' ambientais do agronegócio, que devem ser descontados de qualquer cálculo realista da sua produtividade? $E$, em termos além dos econômicos, dos valores hipotéticos duma 'contabilidade moderna', onde estão todas as outras dimensões, sociais, de sistemas agrários mais inclusivos e sustentáveis: o emprego, a qualidade da comida e da vida, a viabilidade de comunidades rurais e locais, e os impactos urbanos? Todas ainda dependem de uma percepção e solução mais profunda da 'questão agrária', mais persistente do que esta da 'sociabilidade capitalista'.

Das três propostas, nenhuma me parecia sem valor: a dos 7-tesistas, por desafiar a moda de idealizar a realidade dos pequenos produtores, e por sugerir um planejamento baseado em estudos concretos e específicos; a da agricultura familiar, por haver tentado construir alternativas substantivas em redor da produção para autoconsumo e o mercado, e de reconhecer a realidade de uma certa convivência com o agronegócio, por enquanto dominante; e a dos 'campesinistas', por enfatizar uma presença histórica real - a camponesa - apesar de optar por teorizar, antes de examiná-la empiricamente, e daí usá-la indutivamente como um ponto de partida para práticas mais efetivas. Porém, a despeito de suas virtudes, no fundo todas as três respostas parecem menos analíticas do que teleológicas, dedutivas ao invés de indutivas e, assim, pensadas 'de cima para baixo', resultando na mesma qualidade insubstantiva para a formulação e aplicação das políticas agrárias correspondentes. É por isto que chegaram a contribuir tão pouco para atender às necessidades dos assentados, em comparação com qualquer agenda que eles mesmos teriam definido 'de baixo', local e democraticamente.

À questão de se existem camponeses no Brasil, e em que sentindo, poderia ter tido respostas mais claras e aplicáveis se derivasse menos das discussões de Marx e Chayanov do que da observação, mais de perto, do campo brasileiro de hoje. Com base em tudo que eu havia visto, o sentido tão disputado em que pequenos produtores chegavam, de fato, a ser 'camponeses', tornava-se mais simples: não era por eles serem programados à reprodução da família - orientados sim, mas pelo motivo concreto de a família ter sido seu universo social e moral, na ausência histórica da cidadania. Se Zé Francisco e seus companheiros históricos e contemporâneos eram e continuam a ser 'camponeses', cabe a eles decidirem. Portanto, se a resposta for que sim, será em virtude de eles/as serem os únicos brasileiros do campo, 
passados e presentes, capazes de conhecer e viver nele e dele, algo que os dominadores da terra, desde os coronéis até os grandes donos de hoje, individuais e corporativos, todos no fundo colonialistas, nunca fizeram.

Se, num futuro 'pós-Lula', for possível recriar o espaço político para uma alternativa viável, serão os herdeiros dos Zé Franciscos, com seu próprio campesinismo e junto a todos os povos da terra, que terão que defini-lo, 'de baixo'. A questão de como chegar lá está sempre adquirindo mais força por ser de interesse global, tanto para o 'Norte' como para o 'Sul', para o urbano tanto quanto para o rural, com agendas e forças também globais, enquanto ainda precisando respeitar as sensibilidades nacionais (por exemplo, sobre o 'imperialismo verde'). Nesta problemática da sustentabilidade global, o Brasil terá um papel chave: primeiro, graças à sua proporção dos bens comuns globais - florestas, águas, terra e céu; segundo, como ponto de partida, no Ecog2, da nova preocupação global com a sustentabilidade em face do capitalismo global vigente; e, finalmente, pelo exemplo das milhares de lutas invisíveis de todos os Zé Franciscos, prefigurando as opções que todos hoje enfrentamos, nacional e globalmente, entre o bem-estar coletivo ou a ditadura corporativa. Foi Tum quem me mostrou o casebre que seu avô havia construído, depois do falecimento de sua esposa Dona Maria, a antiga guerreira diminuta do enfrentamento de Limpanzol, que, agora, completava quarenta anos (HENFREY, 2017). Ficava meio isolado, no ponto extremo e mais alto da Toca da Onça, escondido pelo mato. Sua frente dava para o poente, atrás do azul-cinza da serra. Embaixo, espalhava-se o espaço vasto e silencioso da Boa Sorte, incluindo Limpanzol, invisível durante uma geração, mas agora identificável novamente, nas casinhas brancas e telhas vermelhas da agrovila.

Segundo Tu, Zé Francisco costumava passar horas aqui, sozinho, e, como eu supunha, sonhando no seu 'mundão véio', sem poder ver esta nova vista, onde seus netos e os netos dos seus companheiros agora embarcavam, no próximo capítulo da luta por uma vida digna. Mais tarde, voltei para passar um tempo ali, com meus sonhos: oxalá eu tivesse como enviarIhe mais uma foto final, desta paisagem transformada. Porém, no fundo, eu sabia que ele não precisaria dela. Com seu poder de ter uma visão de um mundo tão diferente daquele em que ele mesmo nasceu, aquele criador da cidadania para tantos, já teria imaginado esta vista, por si mesmo. 


\section{Referências}

ABRAMOVAY, Ricardo. Paradigmas do Capitalismo Agrário em Questão. 2. ed. SP, Campinas: Editora Unicamp, 1998.

BERNSTEIN, Henry. Food Sovereignty the Peasant Way: a Sceptical View. Journal of Peasant Studies vol. 41, n. 6, 2014.

BORGES, Juliano Luis. MST: do Produtivismo à Agroecologia. 2009 Disponível em: http://www.humanas.ufpr.br/site/evento/SociologiaPolitica/GTs-

ONLINE/GT7\%200nline/mst-produtivismo-JulianoBorges.pdf Acesso em: 03/10/17

BRASIL, Instituto Nacional de Colonização e Reforma Agrária (INCRA). História da

Reforma Agrária. Brasília, 2016. Disponível em:

<http://www.incra.gov.br/reformaagrariahistoria>.

BRASIL/MDA, Secretaria de Agricultura Familiar. Programa Nacional de Produção e Uso de Biodiesel: inclusão social e desenvolvimento territorial. Brasilia, DF: 2010.

BRYANT, R.L.; BAILEY, S. Third World Political Ecology. Routledge, London, 1997 P5

BUAINAIN, A. M.; ALVES, E.; SILVEIRA, J. M da; NAVARRO, Z. Sete teses sobre o mundo rural brasileiro. Revista de Política Agrícola, Ano XXII, No. 2, Brasília, DF, 2013. ( http://www.embrapa.br/publicacoes/tecnico/revistaAgricola/)

CAMPOS, Silvia Kanadani; NAVARRO, Zander. A pequena produção rural e as tendências do desenvolvimento agrário brasileiro: Ganhar tempo é possível? Centro de Gestão e Estudos Estratégicos (CGEE) Brasília, DF, 2013.

CANIELLO, Márcio. Sociologia, Identidade e Qualidade de Vida nos Territórios da Cidadania. Revista da Sociologia, Porto Alegre, ano 18, nº 43, set/dez 2016.

CUNHA, Joaci. Governo Temer: relações do agronegócio com capital especulativo financeiro e os impactos sobre os camponeses e a legislação agrária. Cadernos do CEAS, Salvador/Recife, n. 241, p. 301-326, mai./ago., 2017.

GRAZIANO da SILVA, José. A nova dinâmica da agricultura brasileira. Campinas: Edit UNICAMP, 1996.

HENFREY, Colin. A Cidadania de Zé Francisco e a História 'Feita de Baixo': os Movimentos de Luta pela Terra Parte 1: da Ditadura Militar à Redemocratização. Cadernos do Ceas, Salvador/Recife, n. 240, jan./abr. 2017 p.2.

KAY, Cristóbal. The Agrarian Question and the Neoliberal Rural Transformation in Latin America. European Review of Latin American and Caribbean Studies / Revista Europea de Estudios Latinoamericanos y del Caribe, No. 100, 2014.

MARTINS, José de Souza. O Cativeiro da Terra. 9. ed. São Paulo: Editora Contexto, 2013. 
MATTEI, Lauro. Programa Nacional para Produção e Uso do Biodiesel no Brasil (PNPB): Trajetória, Situação Atual e Desafios. Documentos Técnico-Científicos, Volume 41/4 outdec 2010 Disponível em: https://www.agencia.cnptia.embrapa.br/Repositorio

MATTEI, Lauro. Considerações acerca de teses recentes sobre o mundo rural brasileiro. Rev. Econ. Sociol. Rural, vol. 52 supl.1 Brasília, 2014.

MOYO, Sam.; JHA, Praveen.; YEROS, Paris. The Classical Agrarian Question: Myth, Reality and Relevance Today. Agrarian South: Journal of Political Economy 2(1) 2013.

MURITIBA, Maria Jocélia Souza. Luta pela Terra, Reforma Agrária e Territorialização de Espaço para Trabalho e Vida, Itaeté Bahia, 1997-2007. Dissertação de Mestrado em Planejamento Territorial e Desenvolvimento Social, Universidade Católica do Salvador, 2008.

NAVARRO, Zander. Mobilização sem emancipação - as lutas sociais dos sem-terra no Brasil. In: SANTOS, Boaventura de Sousa (org). Produzir para viver. Rio de Janeiro: Civilização Brasileira, 2002.

ROCHA, Ana Georgina Peixoto. Políticas Públicas e Participação: os atores sociais na política de desenvolvimento territorial do estado da Bahia. Tese de Doutorado na Universidade Federal do Rio Grande do Sul. Faculdade de Ciências, Porto Alegre 2010.

SANTANA DOS SANTOS, Gilson; CAMPELO e SILVA, Felipe Otávio; SANTOS, Valdete. Avaliação do Pronaf no Assentamento Baixão, Itaetê, Bahia, Disponível em http://www.uniara.com.br

UNITED NATIONS World Commission on Environment and Development. Our Common Future. Oxford: Oxford University Press, 1987.

WANDERLEY, Maria de Nazareth Baudel. Agricultura familiar e campesinato: rupturas e continuidade, Estudos Sociedade e Agricultura, Rio de Janeiro, 21, Outubro, 2003: 42-61.

\section{Abreviações}

ATER - Assistência Técnica e Extensão Rural

CPT - Comissão Pastoral da Terra

CONAB - Companhia Nacional de Abastecimento

EMATERBA - Empresa de Assistência Técnica e Extensão Rural - Bahia

INCRA - Instituto Nacional de Colonização e Reforma Agrária

MDA - Ministério de Desenvolvimento Agrário

PNRA - Plano Nacional de Reforma Agrária

PRONA - Programa de Fortalecimento Nacional da Agricultura Familiar 


\section{Agradecimento}

Agradeço a colaboração de Marcos Palácios, da UFBA, e de Joaci Cunha, do CEAS, pela revisão técnica do texto.

\section{Dados do autor}

Colin Henfrey

Professor aposentado de Antropologia Social na Universidade de Liverpool, Inglaterra, colinhenfrey@gmail.com 